\title{
DLK1 wt Allele
}

National Cancer Institute

\section{Source}

National Cancer Institute. DLK1 wt Allele. NCI Thesaurus. Code C99661.

Human DLK1 wild-type allele is located in the vicinity of $14 \mathrm{q} 32$ and is approximately $8 \mathrm{~kb}$ in length. This allele, which encodes protein delta homolog 1, is involved in cell communication. 